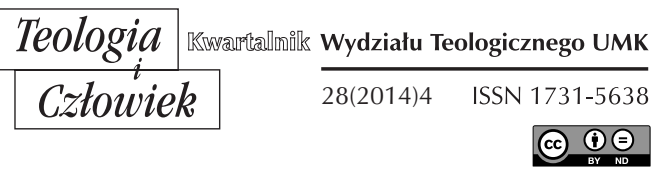

WOJCIECH MALESA*

WARSZAWA

\title{
CHARAKTER MODLITW BŁOGOSŁAWIEŃSTWA W POLSKIM WYDANIU BENEDYKCJONAŁU
}

DOI: http://dx.doi.org/10.12775/TiCz.2014.063

\section{WSTĘP}

Błogosławieństwa są aktami liturgicznymi, sakramentaliami, których sprawowanie oparte jest na autorytecie Kościoła. Mocą jego modlitwy Bóg udziela łask osobom i przedmiotom, które benedykcji dostępują. Sakramentalia te wskazują, że świat widzialny, stworzony przez Boga, jest otoczony Jego opieką. Wszelkie łaski związane z udzielonym błogosławieństwem wskazują na Stwórcę i Jego pełne miłości i hojności działanie wobec ludzi ${ }^{1}$. Udzielanie błogosławieństw związane jest z zastosowaniem pewnych formuł i symboli. Już od czasów pojawienia się i rozwoju oficjalnego kultu starotestamentalnego, poprzez powstanie chrześcijaństwa, wprowadzenie reform Soboru Trydenckiego, aż do pojawienia się współczesnych rytuałów, aktowi przywołania Bożego błogosławieństwa towarzyszą pewne określone słowa i zachowania. Celem niniejszego tekstu jest dokonanie wstępnej analizy formuł występujących w oficjalnej księdze

* Wojciech Malesa - doktorant liturgiki na Wydziale Teologicznym UKSW w Warszawie.

${ }^{1}$ Por. G. Bernacki, Błogostawieństwa w praktyce duszpasterskiej, "Collectanea Theologica", 60 (1990), z. 2, s. 77. 
liturgicznej obowiązującej w Polsce. Badaniu zostaną poddane formuły błogosławieństw pod kątem ich formy lingwistycznej oraz zastosowanie właściwych dla benedykcji gestów i znaków. Wnioski płynące z analizy zostaną zestawione $\mathrm{z}$ aktualnym stanem wiedzy teologicznej.

Obowiązująca w Polsce księga liturgiczna Obrzędy błogosławieństw dostosowane do zwyczajów diecezji polskich (skrót: "OB”) zawiera formuły błogosławieństw na różnorakie okazje życia wiernych. Podzielona została na sześć części:

1) błogosławieństwa dotyczące osób,

2) błogosławieństwa dotyczące budynków i wielorakiej działalności chrześcijan,

3) błogosławieństwa sprzętów liturgicznych i przedmiotów kultu publicznego,

4) błogosławieństwa przedmiotów wyrażających pobożność ludu chrześcijańskiego,

5) błogosławieństwa w różnych okolicznościach,

6) obrzędy błogosławieństw używane $w$ diecezjach polskich.

Struktura księgi, z wyjątkiem części szóstej, stanowi przekład wzorcowej wersji De benedictionibus.

\section{ZARYS HISTORIl BŁOGOSŁAWIEŃSTW}

Od czasów Starego Testamentu Boże błogosławieństwo towarzyszy ludziom. Już w pierwszym rozdziale Genesis znajdujemy słowa benedykcji istot żywych (por. Rdz 1,22) oraz szczególnego błogosławieństwa udzielonego człowiekowi (por. Rdz 1,28). Szczególny nakaz błogosławienia $\mathrm{w}$ imieniu Jahwe skierowany został za pośrednictwem Mojżesza do Aarona i jego synów (por. Lb 6,23-27). Księga Liczb precyzuje, że dawcą błogosławieństwa jest Bóg działający poprzez wezwanie Go nad Izraelitami (por. Lb 6,27). Polski wyraz „błogosławieństwo” pochodzi od łacińskiego benedictio, które znaczy tyle co „dobrze mówić”. Błogosławieństwo jest zatem dobrym życzeniem, przywołaniem Bożej łaski nad osobą. Istnienie błogosławieństwa jest możliwe dzięki aktywności Boga, który jest dawcą wszelkiego dobra. Benedykcja nie działa w sposób „,automatyczny”, ale jest niejako „weryfikowana” przez Boga, wobec czego nie ma cech sakramentalnej skuteczności, ani nie może być utożsamiana z magicznym obrzędem².

${ }^{2}$ Por. W. Chrostowski, Błogostawieństwa $i$ ich znaczenie w Starym Testamencie, „Studia Włocławskie" 14 (2012), s. 55. 
Udzielanie błogosławieństwa wiązało się z wykonaniem konkretnego gestu. Wskazać tu należy przede wszystkim nałożenie rąk na osobę, której udzielano błogosławieństwa (por. Rdz 48,14). Gest ten początkowo zarezerwowany był dla starotestamentalnych kapłanów, z czasem jego wykorzystanie rozszerzono także na lewitów (por. Pwt 10,8; 1 Krn 21,13). Później oprócz tego gestu pojawił się także symbol błogosławieństwa wykonywanego dłonią na kształt krzyża lub kreślenie palcem krzyża na czole osoby błogosławionej. Do powyższych znaków i symboli dodać także należy pokropienie wodą oraz okadzenie ${ }^{3}$. Nie stanowią one „magicznego" rytu błogosławieństwa, ale są podkreśleniem działania Bożego w sprawowanym sakramentalium. W przeciwieństwie do sakramentów (rozróżnienie między sakramentem a sakramentalium ostatecznie wprowadzono w XIII wieku) sakramentalia, a wśród nich także błogosławieństwa, swoją moc czerpią nie z samej skuteczności świętego znaku, ale ex opere operantis Ecclesiae. Każdy akt benedykcji kieruje myśl człowiek do Boga, który jest ostatecznym dawcą łaski ${ }^{4}$.

\section{FORMUŁY EUCHOLOGIJNE}

Najważniejszymi elementami udzielanego błogosławieństwa są głoszenie słowa Bożego i modlitwa Kościoła, „których nigdy nie wolno pominąć, nawet w obrzędach skróconych" (OB 23). Euchologia stosowana $\mathrm{w}$ benedykcjach ma zasadniczo charakter anakletyczno-deprekatywny, gdyż przywołuje działania Boga, odnosi się do Niego jako dawcy wszelkich łask i prosi o udzielenie błogosławieństwa konkretnej osobie. Modlitwy cechuje uwielbienie Boga oraz oparcie tekstu na perykopach Pisma Świętego ${ }^{5}$. Formuly stosowane w obecnej księdze liturgicznej zasadniczo nie odbiegają od kanonu euchologii mniejszej przyjętego w obowiązującym mszale, gdzie występują kolejno: anakleza z podaniem konkretnego

${ }^{3}$ Por. tamże, s. 59; K. Kraczoń, Gest gestów - o znaku krzyża w kulturze ludowej, „Przegląd Religioznawczy”, 2012, nr 4 (246), s. 191.

${ }^{4}$ Por. Cz. Krakowiak, Sakramentalia i błogosławieństwa w liturgii Kościoła, "Ateneum Kapłańskie", 152 (2008), z. 3, s. 522-433; Obrzędy błogostawieństwo dostosowane do zwyczajów diecezji polskich, t. 1-2, Katowice 2001, nr 25-27. Dalej zastosowany zostanie skrót "OB” z podaniem numeru (numery 1-827 zamieszczone są w tomie 1; numery 828-1698 znajdują się w tomie 2).

${ }^{5}$ Por. A. Sierzchuła, Struktura obrzędów błogostawieństw w odnowie soborowej, „Ateneum Kapłańskie”, 152 (2008), z. 3, s. 440-441. 
przymiotu adresata (np. Wszechmogący Boże), anamneza odnosząca się do działania Boga w historii, prośba i konkluzja w jednej z trzech form 6 . Euchologia zazwyczaj kierowana jest do Boga Ojca przez Syna w Duchu Świętym, jednak od tej reguły zdarzają się wyjątki, w których modlitwa skierowana jest do Syna Bożego.

Sama formuła zawarta w euchologiach benedykcji z powodu tożsamości form gramatycznych może być językowo traktowana zarówno jako deprekatywna (błagalna), jak i imperatywna (rozkazująca). Teologia wskazuje jednak, że forma imperatywna nie może mieć zastosowania w tym przypadku ze względu na wolność Boga - człowiek, nawet posiadający święcenia, nie może "przymusić" Stwórcy do konkretnego działania. Modlitwy błogosławieństwa nie stosują także formy indykatywnej, wykorzystywanej w przypadku większości sakramentów („To jest Ciało moje", "Ja odpuszczam tobie grzechy", "Ja ciebie chrzczę" itd.). Forma indykatywna wiąże się z niezaprzeczalną skutecznością znaku, który sprawia to, co oznacza. Błogosławieństwo natomiast może nie przynieść skutku, jeśli człowiek nie zechce z nim współpracować. Wobec powyższego błogosławieństwa są modlitwami deprekatywnymi o udzielenie łaski Bożej dla konkretnej osoby, rzeczy lub w określonej sytuacji.

W językoznawstwie wyróżnia się także kategorię formuł performatywnych, czyli takich, w których nadawca komunikatu, "posługując się odpowiednimi czasownikami performatywnymi, odwołuje się do wyższej instancji, która w wypowiedzi pełni funkcję wykonawczą i odpowiada za skuteczność aktu mowy"7. Formuły te mają charakter deklaratywny, gdyż ich celem jest sprowadzenie na konkretny podmiot określonej łaski poprzez działanie Boga związane z zastosowaniem formuły. Pomimo wypowiedzenia benedykcji przez uprawnioną do tego osobę i stworzenia pewnej rzeczywistości, za to tworzenie odpowiada Stwórca, a skuteczność aktu błogosławieństwa i zakres jego działania zależy od osoby, która łaską ma zostać obdarzona ${ }^{8}$.

${ }^{6}$ Por. K. Porosło, Hermeneutyka liturgiczna kolekt, „Anamnesis”, 67 (2011), nr 4, s. 70; S. Kreczmański, Kolekta w mszale rzymskim. Elementy strukturalne oraz jej wypowiadanie, „Teologia Młodych", 1 (2012), s. 40-53.

7 A. Domagała, Problematyka błogosławieństwa w językoznawstwie $i$ etnolingwistyce, „Śląskie Studia Historyczno-Teologiczne” 45, 1 (2012), s. 112.

${ }^{8}$ Por. tamże, s. 113-115; E. Robek, Formuty i formy modlitewne. Refleksja teologiczna na podstawie Katechizmu Kościoła Katolickiego, „Perspectiva. Legnickie Studia Teologiczno-Historyczne", rok IV 2005, nr 1, s. 125. 
Na potrzeby niniejszego artykułu przyjęto, że za formuły performatywne uznane zostaną te, które wprost używają słów "pobłogosław”, "błogosławię", „,niech udzieli błogosławieństwa” itp. oraz łączą się z wykonaniem określonego gestu błogosławieństwa. Natomiast euchologie, które są wezwaniem Bożej łaski bez wykorzystania słów performatywnych oraz bez wykonania gestów właściwych dla benedykcji, będą określane jako deprekatywne.

\section{SZAFARZE BŁOGOSŁAWIEŃSTW}

Szafarzami błogosławieństw według OB są duchowni oraz świeccy. Wprowadzenie do księgi precyzuje, że do biskupa należy prawo przewodniczenia szczególnie tym błogosławieństwom, które odnoszą się do całej wspólnoty diecezjalnej lub są sprawowane uroczyście przy licznej obecności wiernych. Prezbiterzy mogą sprawować wszystkie benedykcje zamieszczone $\mathrm{w}$ omawianej księdze, diakoni zaś mają możliwość przewodniczenia tym obrzędom, których rubryki na to pozwalają, o ile nie ma duchownych wyższych stopni. Do celebrowania niektórych błogosławieństw zostali dopuszczeni także wierni świeccy (spośród których pierwszeństwo mają akolici i lektorzy). W rubrykach występuje rozróżnienie na kapłanów (czyli biskupów i prezbiterów), celebransów (biskupów, prezbiterów oraz - o ile jest to wyraźnie wskazane - diakonów) i szafarzy (duchownych lub świeckich). Ilekroć pojawia się zatem termin "szafarz", odnosi się on także do świeckiego, który danej liturgii przewodniczy.

Niektóre benedykcje oprócz oracji zawierają także konkretne gesty do wykonania przez szafarza. Gestami tymi są: kreślenie znaku krzyża (por. OB 84, 212, 401 i inne), wyciągnięcie (por. OB 271 i inne) lub nałożenie rąk (por. OB 315 i inne), pokropienie wodą (por. OB 470, 594 i inne) lub okadzenie (por. OB 853, 956 i inne).

Polska księga liturgiczna podaje 210 oryginalnych formuł zatytułowanych jako „modlitwa błogosławieństwa”. Spośród nich 125 jest zarezerwowanych dla osób duchownych, 8 formuł podanych jest do użytku przez świeckich (zwykle jako alternatywy wersji dla duchownych). W OB pojawia się także 77 formuł do stosowania zarówno przez duchowych, jak i przez osoby świeckie9. Samo sprawowanie błogosławieństw jest

${ }^{9}$ W niniejszym zestawieniu celowo pominięto kilka formuł (np. OB 821, 940) z powodu braku formuły błogosławieństwa ustanawiającego lub uświęcającego (w nurcie katabatycznym), o czym w dalszej części. 
obrzędem liturgicznym. Wymaga zatem odpowiedniego skupienia, namaszczenia i powagi, czemu sprzyja zastosowanie obrzędów podanych w księdze liturgicznej. Taka praktyka ułatwi prowadzenie właściwej katechezy mistagogicznej oraz duszpasterstwa liturgicznego ${ }^{10}$.

Duchownym księga przeznacza przede wszystkim błogosławieństwa związane z przedmiotami używanymi w liturgii (np. błogosławieństwo chrzcielnicy, krzesła celebransa, ambony, tabernakulum, drzwi kościoła, organów, dzwonów, krzyża oraz obrazów przeznaczonych do publicznej czci, wody, stacji drogi krzyżowej, cmentarza, wszelakich dewocjonaliów itp.). Większość tekstów zamieszczonych w szóstej części OB (Obrzędy błogosławieństw używane w diecezjach polskich) przeznaczonych jest do wykorzystania jedynie przez duchownych.

Specjalne formuły dla świeckich mają błogosławieństwa związane z rodziną (błogosławieństwo dzieci, synów lub córek, starców, chorych, rodzin i ich członków) oraz błogosławieństwo pokarmów na stół wielkanocny stosowane w rodzinie w uroczystość Zmartwychwstania. Świeccy dopuszczeni są także do udzielania innych błogosławieństw według formuł jednakowych dla nich i dla duchownych, z zastrzeżeniem odmienności wykonywanych gestów. Wskazać tu należy na błogosławieństwa osób, niekoniecznie spokrewnionych (małżonków, narzeczonych, kobiet z okazji urodzenia dziecka, chorych, starców itd.), błogosławieństwa osób związane z pewnymi okolicznościami (katechizacją, podróżą), błogosławieństwa przedmiotów (nowego domu, urządzeń przeznaczonych dla podróżnych, urządzeń technicznych, narzędzi pracy), pokarmów (na stół wielkanocny, opłatków, błogosławieństwa przy stole, owoców przyniesionych do kościoła), jak również błogosławieństwa zwierząt oraz pól, a także „błogosławieństwa z okazji dziękczynienia za otrzymane dobrodziejstwa” i „błogosławieństwa na różne okoliczności”.

Wśród formuł podanych w księdze dominują oracje deprekatywne. Pojawia się w nich formuła „bądź z nami” (por. OB 978, 806, 1349) przyzywająca obecności Boga. Nie przyzywa ona wprost błogosławieństwa, ale prosi o Bożą obecność z tymi, którzy mają dostąpić jego łaski. Słowa te wypowiadane są zarówno z okazji benedykcji osób (np. pielgrzymów, por. OB 417), jak i rzeczy (np. krzyża, por. OB 978). Inną z formuł jest prośba „otaczaj opieką", która zarówno odnosi się do ludzi, jak i na przykład do domu (por. błogosławieństwo nowego domu zakonnego,

${ }^{10}$ Por. K. Konecki, Błogostawieństwa w praktyce duszpasterskiej, „Ateneum Kapłańskie", 152 (2008), z. 3, s. 458-459, 463). 
OB 533). Prośba o „wejrzenie” pojawia się w przypadku błogosławieństw małżonków i rodzin (por. OB 111, 1312h, 128a=134a, 128b=134b) oraz osób wysłanych w celu głoszenia Ewangelii (por. OB 337=351). Prośba ta pojawia się także $\mathrm{w}$ przypadku błogosławieństwa wody poza mszą (wejrzenie na ludzi pokropionych wodą, por. OB 1094), urządzeń technicznych (wejrzenie na korzystających z elektrowni, por. OB 963b) oraz obrazów przeznaczonych do publicznej czci wiernych (wejrzenie na wiernych, którzy wykonali wizerunek, por. OB 1000).

Euchologie stosowane przy udzielaniu błogosławieństw zawierają wezwania rozmaitych skonkretyzowanych form Bożej aktywności wobec człowieka, na przykład: „otaczaj opieką i umacniaj” (OB 58=66), „umocnij ich serca” (OB 211), „prowadź" (OB 248), „podźwignij [...], ulecz, [...], obdarz pociechą" (OB 308), „wyciągnij swoją prawicęe" (OB 315), „osłaniaj” (OB 417), „wspomóż” (OB 445), „okaż swoją łaskę” (OB 676), „pozwól doznawać wstawiennictwa" (OB 1028). Przytoczone zwroty stanowią jakby synonim błogosławieństwa. Wypowiadane są jednak w formułach deprekatywnych, zatem nie stanowią sensu stricto wezwania mocy Boga nad konkretną osobą lub rzeczą, ale są prośbą skierowaną ku Stwórcy o udzielenie konkretnej łaski. Różnorodność stosowanych formuł wskazuje na wielorakość działania Bożego w świecie.

\section{ZNAKI I SYMBOLE BŁOGOSŁAWIEŃSTWA}

Modlitwie błogosławieństwa towarzyszą rozmaite gesty wykonywane wobec błogosławionej osoby lub rzeczy ${ }^{11}$. Najczęściej spotykanym jest pokropienie (OB proponuje je 73 razy dla duchownych i 15 razy dla świeckich). Stosuje się je przy błogosławieństwie miejsc, na przykład domu, mieszkania, seminarium, szkoły, biblioteki, pól, sali katechetycznej, szpitala czy urzędu. Pokropienie występuje także razem z okadzeniem przy błogosławieństwie nowych drzwi kościoła, dzwonów oraz cmentarza. Pokropienie stosowane jest także przy poświęceniu przedmiotów (m.in. pojazdów, pomnika, sztandaru, aparatury medycznej ${ }^{12}$ )

${ }^{11}$ Por. S. Grygiel, Znak błogostawiacy i jego negacja, „Ruch Biblijny i Liturgiczny”, 32 (1979), s. 182-192.

12 Szczegółowa analiza wybranych obrzędów błogosławieństw sprzętów ratowniczych: por. J. Nowak, Obrzęd błogostawieństwa sprzętu pogotowia ratunkowego oraz aparatury medycznej, "Collectanea Theologica”, 68 (1998), z. 4, s. 147-152. 
oraz w większości błogosławieństw z ostatniej części księgi liturgicznej. Kropienie nie jest zarezerwowane tylko dla duchownych. W określonych przypadkach stosować je mogą także świeccy (np. błogosławieństwo pól, nowego domu, pokarmów na stół wielkanocny oraz błogosławieństwa urządzeń i przedmiotów przeznaczonych dla podróżujących). Biblijna symbolika wody odnosi się do aktu stworzenia, Ducha Świętego (Rdz 1,2), ożywienia zmarłych (Ez 36,25), wierności Boga względem ludu (Wj 17,6), pełni życia (Iz 30,23), czystości i płodności ${ }^{13}$. W bogatym znaczeniu symbolu wody i pokropienia nią dostrzec można wielość łask, które Bóg zsyła na swój lud w czasie sprawowania błogosławieństw.

Kolejny stosowanym symbolem błogosławieństwa jest gest wykonywany na kształt krzyża prawą otwartą dłonią (pojawia się w księdze 60 razy). Dotyczy on zarówno osób, jak i przedmiotów. Symbolika tego gestu rozwijana była $w$ historii niemalże od zarania chrześcijaństwa. Widziano w nim zabezpieczenie przeciwko diabłu oraz znak uświęcenia ${ }^{14}$. Początkowo krzyż czyniono kciukiem na czole, dopiero z czasem przekształcił się on do formy znanej obecnie. Pierwotna forma czynienia krzyża również wykorzystana jest w obrzędach błogosławieństw jako znak fakultatywny (6 razy znak ten jest przewidziany dla duchownych, 3 razy dla świeckich) przy udzielaniu błogosławieństwa kobiety w związku z urodzeniem dziecka oraz starców pozostających w domu (błogosławieństwa stosowane przez duchowych) oraz jako znak błogosławieństwa czyniony przez świeckich przy benedykcji chorych.

Rzadziej stosowanym symbolem jest okadzenie. Występuje w OB 19 razy i jest stosowane wyłącznie przez duchownych. Dotyczy ono wyłącznie błogosławieństwa przedmiotów używanych w kulcie (chrzcielnicy, organów, dzwonów, feretronów i innych) oraz cmentarza. Symbol ten znany jest już z czasów starotestamentalnych. W liturgii katolickiej turyfikacja oznacza szacunek, ale także modlitwę wznoszącą się do Boga ${ }^{15}$. Wydaje się, że okadzenie w przypadku benedykcji będzie bardziej obrzędem wyjaśniającym niż znakiem istotnym.

Kolejnym z gestów pojawiającym się przy błogosławieństwach jest nałożenie lub wyciągnięcie rąk. Jest to znak zarezerwowany dla osób duchownych. W obecnej księdze liturgicznej stosowany jest niezwykle

${ }^{13}$ Por. Woda, w: B. Nadolski, Leksykon symboli liturgicznych. Per visibilia ad invisibilia, Kraków 2010, s. 375-376.

${ }^{14}$ Por. Czynienie znaku krzyża, w: tamże, s. 111-112.

${ }^{15}$ Kadzidło, w: Leksykon liturgii, red. B. Nadolski, Poznań 2006, s. 613-616. 
rzadko: nałożenie rąk - 6 razy, wyciągnięcie - 16 razy. Gest ten wykorzystywany jest jedynie przy benedykcjach osób. Nałożenie rąk ma miejsce przy błogosławieństwie chorych i dzieci, wyciągnięcie rąk zaś stosuje się wobec starców, chorych, osób wysłanych w celu głoszenia Ewangelii, rodzin i kobiet przed urodzeniem dziecka lub już po urodzeniu. Gest ten, znany w czasach Starego Testamentu, obecnie oznacza uzdrowienie, błogosławieństwo, dar Ducha Świętego, ustanowienie, posłanie z określoną misją oraz pojednanie ${ }^{16}$.

Rubryki księgi błogosławieństw zezwalają świeckim na użycie następujących znaków:

- pokropienie - w przypadku błogosławieństw domu i przedmiotów dla podróżujących oraz przy benedykcji pól;

- znak krzyża na czole - przy błogosławieństwie chorych.

Wobec wcześniejszych rozważań wydaje się, że czynienie znaku krzyża nad błogosławionym przedmiotem lub osobą powinno być zarezerwowane dla duchownych. Gest ten jednak został umieszczony w OB 1286, 1345, 1381 i innych, które są przeznaczone do użytku zarówno przez duchownych, jak i świeckich. Treść rubryki precyzuje, że duchowni odmawiają orację z rękami rozłożonymi, a świeccy ze złożonymi (notabene takie zróżnicowanie gestów rąk występuje przy wszystkich modlitwach). Choć brakuje formalnego zastrzeżenia, iż świeccy opuszczają wykonanie znaku krzyża, w kontekście całej księgi należy przyjąć, że tak właśnie powinni postąpić.

\section{BŁOGOSŁAWIEŃSTWA A POŚWIĘCENIA}

W tradycyjnej klasyfikacji błogosławieństw rozróżniano błogosławieństwa ustanawiające i wzywające. Te pierwsze, określane czasem mianem „poświęceń", powodowały wyłącznie przedmiotu lub miejsca z użytku świeckiego i przeznaczenie do użytku liturgicznego (np. poświęcenie ołtarza, szat liturgicznych). Poświęcenia z reguły są niepowtarzalne - rzecz raz przeznaczona do sfery sacrum zasadniczo w niej pozostaje, o ile nie zajdą okoliczności powodujące jej zeświecczenie. Błogosławieństwa wzywające są zasadniczo powtarzalne, dotyczą przede wszystkim osób, wiążą się z okolicznościami ich życia, ale także odnosić się mogą

16 Ręce, w: B. Nadolski, Leksykon symboli..., s. 270-275. 
do przedmiotów, którymi posługują się ludzie w celu wyrażenia pobożności ${ }^{17}$. Przykładem będzie tu błogosławieństwo pól - obrzęd nie wyłącza ich z użytku świeckiego, ale jest wyrazem pobożności właścicieli, którzy dziękują Bogu za otrzymane dary i proszą wzywają Jego łaski w rolniczym trudzie.

Współczesny benedykcjonał nie wprowadza przedstawionego powyżej rozróżnienia, jednakże Katechizm Kościoła katolickiego ${ }^{18}$ podkreśla, iż „niektóre błogosławieństwa mają charakter trwały” (KKK 1672) i należy wskazać tu te, które odnoszą się do przedmiotów używanych w liturgii lub przedmiotów kultu. Benedykcje te zostały zawarte w II tomie OB, w części III.

\section{WYBRANE PRZYKŁADY BŁOGOSŁAWIEŃSTW}

Po omówieniu pewnych standardów występujących $\mathrm{w}$ formułach błogosławieństw warto wskazać na kilka osobliwości zawartych w polskim przekładzie księgi.

W numerach OB 166=172b występuje formuła błogosławieństwa dziecka nieochrzczonego. Rubryki przewidują przy niej nałożenie dłoni duchownego na głowę dziecka oraz uczynienie znaku krzyża na czole dziecka przez jego rodziców i szafarza. Słowa euchologii nawiązują do oczekiwanego chrztu: „wejrzyj łaskawie na to dziecko, które ma się odrodzić z wody i Ducha Świętego" (OB 166=172b). Zastrzeżenie, które pojawia się w dalszej części modlitwy, wskazuje niejako na warunek otrzymania łask błogosławieństwa i uzależnia je od przyjęcia chrztu: „Niech po przyjęciu chrztu stanie się uczestnikiem dóbr Twojego królestwa...".

Błogosławieństwo synów lub córek, któremu przewodniczy zasadniczo ojciec lub matka, przewiduje obrzęd krótki, zapisany w OB 194. Formuła (również przeznaczona do wykorzystania przez świeckich) brzmi: „Niech Pan was strzeże i pozwoli wam wzrastać w swojej miłości, abyście godnie postępowali na drodze powołania, którym was obdarzył" (OB 194). Tekst ten ma charakter performatywny („Niech Pan was strzeże"), zbliżony do końcowego błogosławieństwa udzielanego na przykład we mszy świętej („Niech was błogosławi...”). Jest to jeden z wyjątków,

${ }^{17}$ Por. D. Brzeziński, Znaczenie błogostawienia osób w świetle Katechizmu Kościoła katolickiego i "Obrzędów btogostawieństw", „Anamnesis”, 15 (2009), nr 2, s. 89-90.

${ }^{18}$ Katechizm Kościota katolickiego, Poznań 2002; dalej: KKK. 
kiedy przepis dopuszcza stosowanie takiej formuły przez osobę świecką. Zasadniczo forma performatywna zarezerwowana jest dla duchownych, którzy na mocy przyjętego sakramentu święceń posiadają władzę ministerialną. W omawianym przypadku dopuszczalność formuły tego typu wynika nie tylko z kapłaństwa wspólnego, w którym uczestniczą rodzice dziecka (jako szafarze), ale także z ich wyjątkowej roli, jaką spełniają wobec dziecka.

Dla porównania OB 228 podaje formułę benedykcji kobiety przed urodzeniem dziecka. Nie pojawiają się w niej słowa błogosławieństwa („pobłogosław”, „niech cię błogosławi” itp.). Występuje natomiast wstawiennicze wezwanie szafarza do Boga: „Przyjmij łaskawie pokorne modlitwy swojej służebnicy..." (OB 228). Formuła ta ma charakter deprekatywny. Duchowny może wyciągnąć ręce nad kobietą lub nakreślić na jej czole znak krzyża. Gest ten w połączeniu z dalszą częścią benedykcyjnej euchologii nabiera charakteru niemal performatywnego. W słowach „niech szczęśliwie urodzi swoje dziecko...” doszukać się można prośby lub stworzenia konkretnej przestrzeni działania Boga - oto Kościół przez usta szafarza (duchownego lub świeckiego) „prosi łaskawie” o konkretny dar szczęśliwego rozwiązania. Pomimo jednak zastosowania gestu charakterystycznego dla formuł performatywnych, z uwagi na dopuszczalność użycia formuły przez świeckich oraz brak słów jednoznacznych dla błogosławieństwa, euchologia ta została zaliczona do deprekatywnych.

Błogosławieństwo pielgrzymów zawiera formułę podobną do komentowanej powyżej: „prosimy Cię, obdarz ich hojnym błogosławieństwem" (OB 428). Wskazane są także konkretne łaski, których doświadczyć mają pielgrzymi: „niech z radością powrócą do domów, słowami i życiem głosząc wszystkim Twoje cuda". Do uznania tej modlitwy jednoznacznie za performatywną brakuje przede wszystkim wykonania znaku krzyża. Wydaje się jednak, że z uwagi na treść oracji oraz posłużenie się słowem „błogosławieństwo" (choć wyraźnie w formie deprekatywnej) modlitwę tę można zaliczyć do performatywnych.

Podobnie modlitwa błogosławieństwa osób wyruszających w podróż, choć nie zawiera żadnego gestu, sformułowana została w formie performatywnej: „Niech nas Bóg obdarzy wszelkim błogosławieństwem z nieba..." (OB 452). Benedykcja ta może być wypowiadana zarówno przez duchownego, jak i świeckiego. Warto tu zwrócić uwagę na zastosowaną formę gramatyczną i użycie pierwszej osoby liczby mnogiej. 
Euchologia została podana jako alternatywa do OB 451, co wskazywałoby, że powinna być stosowana, gdy szafarz błogosławieństwa udaje się w podróż razem z pozostałymi uczestnikami modlitwy.

Podobnie przy błogosławieństwie przy stole (por. OB 785, 798, $804,808,811,815,817,820$ ) wykorzystywane są wielokrotnie formuły o treści językowo performatywnej. Duchowni wykonują przy nich gest benedykcji, kreśląc znak krzyża nad posiłkiem. Świeccy gest ten opuszczają. Niemniej jednak formuły spełniają wymogi lingwistyczne do uznania ich za performatywne.

Wśród błogosławieństw przy stole pojawia się także formuła o wyjątkowym charakterze. Zawiera ona trzy błogosławieństwa skierowane do Osób Trójcy Świętej, nie zawiera natomiast żadnego wezwania performatywnego czy nawet deprekatywnego. Pierwsze z wezwań brzmi: „Błogosławiony jesteś, wszechmogący Ojcze, Ty nam udzielasz codziennego chleba" (OB 821). Kolejne skierowane są do Syna Bożego i Ducha Świętego i zawierają błogosławieństwa za działanie Trójcy Świętej w życiu ludzi. Choć euchologia z OB 821 jest błogosławieństwem sensu largo, to jednak nie została sklasyfikowana pod względem formy.

Obrzęd błogosławieństwa z okazji oddania do użytku nowego konfesjonału nie powinien być łączony ze sprawowaniem mszy. Rubryki obrzędu błogosławieństw sugerują, aby sprawować go przy okazji nabożeństw pokutnych (por. OB 930-931). Wprowadzenie do obrzędu wskazuje, że błogosławieństwo to jest $\mathrm{w}$ istocie dziękczynieniem skierowanym do Boga (por. OB 935). Po czytaniach biblijnych w obrzędzie następują "prośby". Ich formuła jednak nie zawiera żadnego wezwania błagalnego, lecz stanowi dziękczynienie Bogu za łaski związane z odpuszczeniem grzechów. Oracja, następująca po „prośbach”, oparta jest na dziękczynieniu, z pewnymi analogiami do budowy prefacji:

Godne to jest i sprawiedliwe, abyśmy zawsze i wszędzie Tobie składali dziękczynienie, wszechmogący, wieczny Boże.

Ty w swoim miłosierdziu sprawiedliwie karzesz i łaskawie przebaczasz; gdy zsyłasz karę, chcesz nas uchronić od wiecznej zguby; kiedy darujesz winę, dajesz nam czas do poprawy życia. Przez Chrystusa, Pana naszego ${ }^{19}$.

Dziwić może zastosowanie konkluzji po drugiej części oracji. W przypadku komentowanej euchologii nie pojawia się żadna prośba,

19 OB 940. 
a jedynie uwielbienie Boga za Jego działanie. Choć nazwa „błogosławieństwo" jest w tym momencie teologicznie uzasadniona ${ }^{20}$, to jednak zabrakło oczekiwanego błogosławieństwa w nurcie katabatycznym, jak na to miejsce $\mathrm{w}$ przypadku większości błogosławieństw zamieszczonych w OB. Można uznać, że formuła zapisana w OB 940 stanowi sensu stricto "dziękczynienie" o charakterze anabatycznym.

Obrzęd błogosławieństwa wody w formie zapisanej w OB 1095 ma formułę dialogiczną. Celebrans kieruje modlitwę do Trójjedynego Boga i anamnetyzuje $\mathrm{w}$ niej działanie Boga w historii. Zgromadzeni odpowiadają aklamacją „Błogosław i oczyszczaj swój Kościół”. Owa aklamacja stanowi jedyną formułę deprekatywną w komentowanej euchologii, co wskazuje, iż błogosławieństwo przychodzi przez modlitwę wspólnoty Kościoła.

\section{PODSUMOWANIE}

Przedstawione powyżej efekty studium treści benedykcji zawartych w Obrzędach błogosławieństw dostosowanych do zwyczajów diecezji polskich wskazują na różnorodność form stosowanych przy błogosławieniu. Wyróżniono formuły deprekatywne (130 razy) oraz performatywne (80 razy). Przy rozróżnianiu charakteru oracji ustalono następującą metodologię:

1) użycie formuł performatywnych lub gestów charakterystycznych dla błogosławieństw było przesłanką za zaklasyfikowaniem danej oracji jako performatywnej,

2) budowa i treść, która mogłaby być wykorzystana jako kolekta, wskazywały na klasyfikację danej oracji jako deprekatywnej.

Teksty euchologii mają zwykle budowę zbliżoną do kolekty - zawierają zwrot do Boga jako dawcy błogosławieństwa, wspomnienie Jego działania w historii lub uwielbienie Go za to działanie, sformułowanie prośby oraz konkluzję. Formuła o charakterze deprekatywnym często nie zawiera słowa "błogosławieństwo", a zastępuje je innymi, konkretyzującymi sposób działania Boga, np. „spraw”, "otaczaj opieką", „osłaniaj”, „wspomóż".

Wskazano także na dwie formuly (por. OB 821 i 940), które nie mają charakteru błogosławieństwa w nurcie zstępującym, a stanowią

${ }^{20}$ Por. D. Brzeziński, dz. cyt., s. 90. 
uwielbienie Boga za Jego działanie lub opowiadanie o tejże aktywności Stwórcy.

Formułom benedykcji towarzyszą także gesty, wśród których wymienić należy między innymi kreślenie znaku krzyża palcem na czole osoby błogosławionej albo dłonią nad błogosławionymi osobami lub rzeczami. Wśród symboli towarzyszących błogosławieństwom znajdują się także pokropienie wodą błogosławioną (dopuszczalne jest użycie tego symbolu przez świeckich szafarzy błogosławieństw) oraz okadzenie (stosowane jedynie przez duchownych).

Formuła błogosławieństw nie ma charakteru indykatywnego, jak w przypadku większości sakramentów, zatem skuteczność tego sakramentalium jest zależna przede wszystkim od woli Boga oraz od dyspozycji przyjmującego błogosławieństwo. Skuteczność błogosławieństw udzielanych katechumenom uzależniona została w euchologiach od przyjęcia przez nich chrztu.

\section{ZAKOŃCZENIE}

Celem niniejszego artykułu było dokonanie wstępnej analizy formuł benedykcyjnych oraz towarzyszących im znaków. Jak wykazano powyżej, badanie doprowadziło do dokonania podziału tekstów pod względem ich formy, podania katalogu gestów i symboli towarzyszących benedykcjom oraz określenie dopuszczalności ich stosowania przez poszczególne grupy szafarzy. Niejednokrotnie dziwić może brak jednoznacznego sformułowania błogosławieństwa (przez zastosowanie imperatywnego lub indykatywnego trybu czasownika „błogosławić”), co wiąże się z zastosowaniem formuły o charakterze błagalnym oraz precyzowaniem formy działalności Boga w życiu osób błogosławionych lub korzystających z błogosławieństwa. Przedstawione powyżej wnioski dotyczące błogosławieństw mogą stać się podstawą do podjęcia dalszej refleksji.

Streszczenie. Od czasów pojawienia się i rozwoju oficjalnego kultu starotestamentalnego, poprzez powstanie chrześcijaństwa, aż do pojawienia się współczesnych rytuałów, aktowi przywołania Bożego błogosławieństwa towarzyszą określone słowa i zachowania. Najważniejszymi elementami udzielanego błogosławieństwa są głoszenie słowa Bożego i modlitwa Kościoła wzywająca działania Bożego. Stosowane oracje mają charakter deprekatywny (błagalny) lub performatywny (przywołująco-ustanawiający). 
Według przepisów szafarzami błogosławieństw są głównie duchowni, chociaż niektóre benedykcje wypowiadać mogą także świeccy. Obrzędy, w zależności od stosującego je szafarza, różnią się zastosowaniem gestów i symboli towarzyszących wypowiadanym modlitwom. Zasadniczo dla duchownych zarezerwowane jest czynienie znaku krzyża nad błogosławionymi osobami lub przedmiotami, wyciągnięcie i nałożenie rąk oraz okadzanie. Gesty te nie stanowią o błogosławieństwie, są jedynie uzupełnieniem modlitw benedykcyjnych.

Euchologie stosowane przy udzielaniu błogosławieństw zawierają wezwania rozmaitych skonkretyzowanych form Bożej aktywności wobec człowieka, na przykład: „otaczaj opieką i umacniaj”, „umocnij ich serca”, „prowadź”, „podźwignij [...], ulecz, [...], obdarz pociechą", „wyciągnij swoją prawicę", „osłaniaj”, „wspomóż”, „okaż swoją łaskę", „pozwól doznawać wstawiennictwa”. Przytoczone zwroty stanowią synonimy błogosławieństwa. W księdze liturgicznej znajdują się także formuły, które nie mają charakteru błogosławieństwa w nurcie zstępującym, a stanowią uwielbienie Boga za Jego działanie lub opowiadanie o tejże aktywności.

W artykule przedstawiono katalog gestów i symboli stosowanych przy udzielaniu błogosławieństwa. Omówiono także charakter stosowanych formuł euchologijnych oraz wskazano na dopuszczalność stosowania konkretnych znaków przez poszczególnych szafarzy.

Słowa kluczowe: błogosławieństwa; formuły; znaki i symbole.

Summary: Since the appearance and development of the official OldTestament cult, through the origin of Christianity, till the coming into being of contemporary rites, the act of summoning God's blessing has been accompanied by specific words and behaviour. The most significant elements of the act of giving God's blessing include preaching the Word of God and the prayer of the Church, which summons God's action. Appropriate orations are of depricative (imploring) or performative (summoning-appointing) character.

According to the rules it is mostly clergymen who can be the ministers of blessings, although some benedictions might be expressed by the laymen as well. The rites, depending on the minister who performs them, may differ in terms of the application of gestures and symbols which accompany the prayers said. Generally, it is a reserved right for the clergy to make the sign of the Cross over the people or items to be blessed, perform the acts of extending and the laying on of the hands, as well as incensing. These gestures do not constitute the blessing itself; they are merely the complementation of benediction prayers.

Euchologies applied while giving the blessings contain the summons of various specified forms of God's activity towards human beings, for example: 'surround them with your care and make them strong', 'strengthen their hearts', 'guide them', 'lift them [...], heal them [...], give them comfort', 'take your Right Hand', 'shield them', 'aid them', 'show Your mercy', 'allow them to feel Your intercession'. All the formulas to which it has been referred to above constitute 
the synonyms for blessing. In the liturgy book there are also such formulas which are not blessings but constitute the act of adoration of God for His actions or the recollection of these actions.

The article presents the catalogue of gestures and symbols applied while giving the blessing. Furthermore, the character of euchologic formulas was discussed and the admissibility of applying particular signs by given ministers was indicated.

Keywords: blessings; formulas; signs and symbols. 